\title{
Mitigative Effect of Bacillus subtilis QM3 on Root Morphology and Resistance Enzyme Activity of Wheat Root under Lead Stress
}

\author{
Yang Hao, Haitao Wu, Yanfang Liu, Qingping $\mathrm{Hu}^{*}$ \\ College of Life Science, Shanxi Normal University, Linfen, China \\ Email: ${ }^{*}$ hqp72@163.com
}

Received 3 June 2015; accepted 26 June 2015; published 29 June 2015

Copyright (C) 2015 by authors and Scientific Research Publishing Inc.

This work is licensed under the Creative Commons Attribution International License (CC BY).

http://creativecommons.org/licenses/by/4.0/

(c) $\underset{\mathrm{EY}}{\mathrm{B}}$ Open Access

\section{Abstract}

Lead $(\mathrm{Pb})$ is an environmental pollutant extremely toxic to plants and other living organisms including humans. In order to research the relieve effect of Bacillus subtilis QM3 on wheat roots (Triticum aestivum L.), after wheat seeds germination for two days, wheat root caused, the experimental materials were divided into four large groups and each large group was placed in 6 petri dishes as six small groups, and then four large groups respectively cultivated with sterile water (CK), $10^{8} \mathrm{CFU} / \mathrm{ml}$ B. subtilis QM3 (B1), $10^{7} \mathrm{CFU} / \mathrm{ml}$ B. subtilis QM3 (B2) and $10^{6} \mathrm{CFU} / \mathrm{ml} \mathrm{B}$. subtilis QM3 (B3) for 2 days, after that stressed with lead nitrate, $\mathrm{Pb}\left(\mathrm{NO}_{2}, \mathrm{~Pb}^{2+}\right.$ concentration calculation at five concentrations $(50,250,500,1000,2000 \mathrm{mg} / \mathrm{L})$, sterile water and different $\mathrm{Pb}^{2+}$ concentration liquid respectively cultivated the 6 small groups in each large group measuring root morpholog and assaying changes of antioxidant enzyme activity. The results showed that: with the increase of the $\mathrm{Pb}^{2+}$ concentration, root morphology index and the activity of antioxidant enzyme increased first and then decreased. Root morphology index reached the maximum in $50 \mathrm{mg} / \mathrm{L} \mathrm{Pb}^{2+}$ concentration. $B$. subtilis $\mathrm{QM} 3$ clearly promoted the growth of the root and the antioxidant enzyme activity $(p<0.05)$. Without $\mathrm{Pb}$ stress, $B$. subtilis $\mathrm{QM} 3$ had the best improving effect on root morphology. When $\mathrm{Pb}^{2+}$ concentration was $50 \mathrm{mg} / \mathrm{L}$, superoxide dismutase (SOD) and ascorbate peroxidase (APX) reached the maximum. SOD activity, compared with CK, B1, B2 and B3 respectively, increased by $8.05 \%, 27.41 \%$ and $9.79 \%$. APX activity, compared with CK, B1, B2 and B3 respectively, increased by $52.70 \%, 111.15 \%$ and $14.16 \%$. Catalase (CAT) and peroxidase (POD) reached the maximum at the $\mathrm{Pb}^{2+}$ concentration was $500 \mathrm{mg} / \mathrm{L}$. CAT activity, compared with CK, B1, B2 and B3 respectively, increased by $59.93 \%, 83.46 \%$ and $70.59 \%$. POD activity, compared with CK, B1, $B 2$ and $B 3$ respectively, increased by $2.88 \%, 10.11 \%$ and $7.67 \%$. Result suggested that $B$. subtilis QM3 could improve root growth and antioxidant enzyme activity of the wheat root under lead stress.

\footnotetext{
${ }^{*}$ Corresponding author.

How to cite this paper: Hao, Y., Wu, H.T., Liu, Y.F. and Hu, Q.P. (2015) Mitigative Effect of Bacillus subtilis QM3 on Root Morphology and Resistance Enzyme Activity of Wheat Root under Lead Stress. Advances in Microbiology, 5, 469-478. 


\section{Keywords}

\section{B. subtilis QM3, Resistance Enzyme Activity, Root Morphology, Lead Stress}

\section{Introduction}

With the rapid expansion of the city and the rapid development of the modern industry and agriculture, the pollution of heavy metals in natural environment is becoming more and more serious. Lead $(\mathrm{Pb})$, one of the oldest known metals, is a pervasive and persistent environmental occupational toxic metal, and $\mathrm{Pb}$ poisoning remains a health threat [1]. The release of $\mathrm{Pb}$ represents a serious problem for human life by entering the food chain. A variety of environmental stresses like soil salinity, drought, extreme of temperature and heavy metals are known to cause oxidative damage to plants either directly or indirectly by triggering an increased level of production of reactive oxygen species (ROS) [2]-[7]. Lead toxicity to plants is mainly because of heavy metal destroyed the normal physiological function in plant, heavy metal toxicity may also be exerted by the fact that heavy metals induce secondary oxidative stress by importing the formation of harmful reactive oxygen species (ROS) [8]. These ROS include superoxide $\left(\mathrm{O}_{2}^{-}\right)$, hydroxyl radical $\left(\mathrm{OH}^{-}\right)$and hydrogen peroxide $\left(\mathrm{H}_{2} \mathrm{O}_{2}\right)$ that are produced as by products during membrane linked electron transport activities as well as by a number of metabolic pathways [4] and in turn cause damage to the biomolecules such as membrane lipids, proteins, chloroplast pigments, enzymes, and nucleic acids [5]. When lead enters the plant cells, like various heavy metals, it induces an oxidative stress in growing plant parts due to enhanced production of reactive oxygen species (ROS), and cell damages result in a reduction of plant productivity [9] [10].

To combat the oxidative damage plants have the antioxidant defense system comprising of superoxide dismutase (SOD), catalase (CAT), peroxidase (POD) and ascorbate peroxidase (APX).

Wheat is one of the major grain crops in the world. The global annual demands have increased year by year, but due to the deterioration of the environment and other unfavorable factors severely restrict the increase of wheat yield. Study on the growth of lead early effects on crops, has been a focus of the field of ecological environment in recent years. The root is the most important part of the combination of heavy metals in plants, and is also the most vulnerable part to heavy metal toxicity. It is the underground vegetative organs of plants, playing a very important role in crop production. Therefore, the study on effects of heavy metal in soil on plant root system is of important significance.

A few studies on alleviation of heavy metal stress-induced inhibition of activity of antioxidant enzyme have been published. However, in relation to bacteria, the studies on the alleviation effect of bacteria on plant growth under heavy metals stress are limited. To understand the biology of plants and microbial ecology, many studies performed with bacteria have focused on evaluating the colonization pattern of vegetative tissues, as well as the effects of bacteria on plant growth [11]. B. subtilis QM3 is a strain of antagonistic strains which have biological control function. It was isolated from dung of QingHai yak. Careful study is necessary to determine whether $B$. subtilis QM3 can alleviate inhibition of wheat root growth which is induced by heavy metal stress. Previous study showed that $B$. subtilis QM3 had an auxo-action on wheat seed germination and had a promotion effect on the growth of tomato.

This experiment is intended to investigate the alleviation effect of B. subtilis QM3 on growth and enzyme activities of wheat roots that under different concentration of lead stress; it will be helpful to identify toxic critical values of $\mathrm{Pb}$ in soils due to wheat's response, and lay a theoretical foundation for the alleviation of heavy metal pollution and the original innovation of microbial inocula.

\section{Materials and Methods}

\subsection{Plant Material and Bacterial Suspension Preparation}

Wheat seeds from the Research Institute of wheat in Shanxi Province, China. B. subtilis strain QM3 (College of life science, Shanxi Normal University, China) was grown at $37^{\circ} \mathrm{C}$ for $3 \mathrm{~d}$ in nutrient broth (NB) medium, under vigorous shaking $(150 \mathrm{rpm})$. Cultures were centrifuged once at $3000 \mathrm{~g}$ for $5 \mathrm{~min}$ at $20^{\circ} \mathrm{C}$ to collect the bacteria and then rinsed three times with sterile water, and diluted in sterile water solution in order to reach an $\mathrm{OD}_{600 \mathrm{~nm}}$ 
of $0.8\left(10^{8} \mathrm{CFU} / \mathrm{ml} \mathrm{B}\right.$. subtilis QM3). At the same time diluted the bacterial suspension liquid 10 times (10 $\mathrm{CFU} / \mathrm{ml}$ B. subtilis QM3) and 100 times $\left(10^{6} \mathrm{CFU} / \mathrm{ml}\right.$ B. subtilis QM3) to reserve.

\subsection{Plant Treatment and Lead Stress Conditions}

Wheat seeds were surface-sterilized with $0.1 \%$ Mercuric chloride solution for $10 \mathrm{~min}$ and then rinsed three times with sterile water. Then soaked in sterile water for $24 \mathrm{~h}$ and then transferred to Petri dishes for germination. After two days' germination, root caused, then transferred the uniform growth of wheat seeds to other Petri dishes, seedlings were divided into four large groups, each group was placed in 6 petri dishes as six small group, four large groups respectively cultivated with sterile water (CK), $10^{8} \mathrm{CFU} / \mathrm{ml}$ B. subtilis QM3 (B1), $10^{7} \mathrm{CFU} / \mathrm{ml}$ B. subtilis QM3 (B2) and $10^{6} \mathrm{CFU} / \mathrm{ml}$ B. subtilis QM3 (B3) for 2 days. $\mathrm{Pb}\left(\mathrm{NO}_{3}\right)_{2}$ treatment performed on the fifth day, $\mathrm{Pb}^{2+}$ concentration calculation at five concentrations $(50,250,500,1000,2000 \mathrm{mg} / \mathrm{L}$ ), sterile water and different $\mathrm{Pb}^{2+}$ concentration liquid respectively cultivated the 6 small groups in each large group for 4 days, after that root morphology index and resistance enzyme activity were evaluated. The seedlings were grown in a constant temperature light incubator $\left(25^{\circ} \mathrm{C}\right.$ day $/ 20^{\circ} \mathrm{C}$ night; $12 \mathrm{~h} / 12 \mathrm{~h}$, light/dark period; and $55 \%$ relative humidity).

\subsection{Root Growth Analysis}

After 9 days' growth, three uniform seedlings were selected from each Petri dish for the determination of root growth by using Root scanner. All measurements were performed in three replicates.

\subsection{SOD Assay}

SOD activity was measured through the photo-reduction of nitro blue tetrazolium chloride (NBT) [12]. About $500 \mathrm{mg}$ fresh tissues were homogenized in $5 \mathrm{ml}$ of $100 \mathrm{mM}$ Na-phosphate buffer (pH 7.8) containing $0.1 \mathrm{mM}$ EDTA, $0.1 \%(\mathrm{v} / \mathrm{v})$ Triton X-100 and $1 \%(\mathrm{w} / \mathrm{v})$ polyvinyl pyrrolidone (PVP). The extract was centrifuged at $8000 \times \mathrm{g}$ for $30 \mathrm{~min}$ at $4^{\circ} \mathrm{C}$. The reaction mixture contained $50 \mu \mathrm{L}$ of $33 \mathrm{mM} \mathrm{NBT}, 100 \mu \mathrm{L}$ of $10 \mathrm{mM}$ L-methionine, $50 \mu \mathrm{L}$ of $0.0033 \mathrm{mM}$ riboflavin in $250 \mu \mathrm{L}$ of $50 \mathrm{mM}$ sodium phosphate buffer. The reaction mixture was placed under lamp below $15 \mathrm{~W}$ for 25 min before the reaction was stopped by switching off the light. Non-illuminated and illuminated reactions without supernatant served as control. The absorbance was measured at 560 $\mathrm{nm}$. One unit of SOD activity was defined as the quantity of SOD required to produce a $50 \%$ inhibition of NBT.

\subsection{CAT Assay}

The activity of CAT was assayed according to Beers and Sizer [13]. Fresh samples (500 mg) were homogenized in $5 \mathrm{ml}$ of $50 \mathrm{mM}$ Tris/NaOH buffer (pH 8.0) containing $0.5 \mathrm{mM}$ EDTA, 1\% (w/v) PVP and $0.5 \%(\mathrm{v} / \mathrm{v})$ Triton $\mathrm{X}-100$. The homogenate was centrifuged at $8000 \times \mathrm{g}$ for $30 \mathrm{~min}$ at $4{ }^{\circ} \mathrm{C}$ and after dialysis supernatant was used for enzyme assay. Assay mixture in a total volume of $3.0 \mathrm{ml}$ contained $2000 \mu \mathrm{l}$ of $100 \mathrm{mM} \mathrm{NaH}_{2} \mathrm{PO}_{4}$ buffer $(\mathrm{pH}$ 7.0), $800 \mu \mathrm{l}$ of $200 \mathrm{mM} \mathrm{H}_{2} \mathrm{O}_{2}$ and $200 \mu \mathrm{l}$ enzyme. The decomposition of $\mathrm{H}_{2} \mathrm{O}_{2}$ was followed at $240 \mathrm{~nm}$ (extinction coefficient of $0.036 \mathrm{mM}^{-1} \cdot \mathrm{cm}^{-1}$ ) by decrease in absorbance. Enzyme specific activity is expressed as mmol of $\mathrm{H}_{2} \mathrm{O}_{2}$ oxidized $\min ^{-1}$ (mg protein) ${ }^{-1}$.

\subsection{APX Assay}

About $500 \mathrm{mg}$ root sample were homogenized in $5 \mathrm{ml}$ of $50 \mathrm{mM}$ Na-phosphate buffer (pH 7.8) containing 1\% PVP, $1 \mathrm{mM}$ ascorbic acid and $1 \mathrm{mM}$ PMSF as described by Moran et al. [14]. After centrifugation at $8000 \times \mathrm{g}$ for $30 \mathrm{~min}$ at $4^{\circ} \mathrm{C}$, the supernatant was dialyzed against the same extraction buffer and it served as enzyme. APX was assayed according to Nakano and Asada [15]. Reaction mixture in a total volume of $1 \mathrm{ml}$ contained $50 \mathrm{mM}$ K-phosphate buffer (pH 7.0), $0.2 \mathrm{mM}$ ascorbic acid, $0.2 \mathrm{mM}$ EDTA, $20 \mathrm{mM} \mathrm{H}_{2} \mathrm{O}_{2}$ and enzyme. $\mathrm{H}_{2} \mathrm{O}_{2}$ was the last component to be added and the decrease in absorbance was recorded at $290 \mathrm{~nm}$ (extinction coefficient of 2.8 $\mathrm{mM}^{-1} \mathrm{~cm}^{-1}$ ) using a UV-Vis spectrophotometer at $30 \mathrm{~s}$ intervals up to $7 \mathrm{~min}$. Correction was made for the low, non enzymic oxidation of ascorbic acid by $\mathrm{H}_{2} \mathrm{O}_{2}$. The specific activity of enzyme is expressed as mmol ascorbate oxidized $\mathrm{min}^{-1}$ (mg protein) ${ }^{-1}$.

\subsection{POD Assay}

Samples (500 mg) were ground in potassium-phosphate buffer, pH 6.1 (1 ml $100 \mathrm{mg}^{-1}$ fresh weight) with PVP 
(1.0 $\mathrm{g} \cdot \mathrm{g}^{-1}$ of fresh weight) at $4^{\circ} \mathrm{C}$ and centrifuged for $30 \mathrm{~min}$ at $8000 \mathrm{rpm}$. Supernatant was used as the crude enzyme extract. Peroxidase activity was assayed spectrophotometrically at $25^{\circ} \mathrm{C}$ following the oxidation of guaiacol. The reaction mixture consisted in $100 \mu \mathrm{l} 20 \mathrm{mM}$ guaiacol and $100 \mu 10 \mathrm{mM} \mathrm{H}_{2} \mathrm{O}_{2}$ in $700 \mu \mathrm{l}$ potassium-phosphate buffer $\mathrm{pH}$ 6.1. One hundred microlitres of each crude enzyme extract was added, and the increase in absorbance at $470 \mathrm{~nm}$ was followed. Enzyme activity was expressed as absorbance per minute per mg protein $\left(\Delta \mathrm{Abs} \mathrm{min}^{-1} \cdot \mathrm{mg}^{-1}\right.$ protein). Protein concentration was determined by the Bradford method [16].

\subsection{Statistical Analysis}

One way analysis of variance (ANOVA) and Duncan's multiple range tests were carried out to determine significant differences $(\mathrm{p}<0.05)$ between the means by Data Processing System (DPS, version 7.05) and EXCEL program.

\section{Results}

\subsection{Mitigative Effect of $B$. subtilis QM3 on the Growth of Root}

Lead nitrate treatment results in the variation of root morphology (Table 1). As shown in Table 1, when without

Table 1. Effects of $B$. subtilis QM3 on the growth of root under lead stress.

\begin{tabular}{|c|c|c|c|c|c|}
\hline $\mathrm{Pb}^{2+}$ concentration $(\mathrm{mg} / \mathrm{L})$ & Treatment & Len $(\mathrm{cm})$ & $\mathrm{SA}\left(\mathrm{cm}^{2}\right)$ & $\operatorname{Vol}\left(\mathrm{cm}^{3}\right)$ & $\mathrm{PA}\left(\mathrm{cm}^{2}\right)$ \\
\hline \multirow{4}{*}{0} & CK1 & $5.35 \pm 0.01 c$ & $28.86 \pm 1.50 \mathrm{~d}$ & $12.33 \pm 1.03 c$ & $9.12 \pm 0.98 d$ \\
\hline & B1 & $9.46 \pm 0.06 \mathrm{~b}$ & $45.19 \pm 0.12 c$ & $36.14 \pm 0.10 b$ & $14.43 \pm 0.14 \mathrm{c}$ \\
\hline & B2 & $10.26 \pm 0.10 \mathrm{a}$ & $104.27 \pm 3.62 \mathrm{a}$ & $90.57 \pm 0.57 \mathrm{a}$ & $34.41 \pm 0.50 \mathrm{a}$ \\
\hline & B3 & $9.51 \pm 0.04 \mathrm{~b}$ & $58.68 \pm 0.02 b$ & $36.61 \pm 0.04 b$ & $18.69 \pm 0.02 b$ \\
\hline \multirow{4}{*}{50} & CK2 & $12.41 \pm 0.03 b$ & $91.49 \pm 1.14 b$ & $54.45 \pm 0.48 c$ & $29.27 \pm 1.04 b$ \\
\hline & B1 & $13.09 \pm 0.03 \mathrm{a}$ & $50.54 \pm 0.69 d$ & $49.07 \pm 0.07 d$ & $15.78 \pm 0.34 d$ \\
\hline & B2 & $7.52 \pm 0.37 \mathrm{c}$ & $68.40 \pm 0.35 c$ & $72.48 \pm 0.67 a$ & $21.49 \pm 0.29 c$ \\
\hline & B3 & $6.97 \pm 0.38 d$ & $102.27 \pm 4.66 \mathrm{a}$ & $70.39 \pm 0.95 b$ & $34.46 \pm 0.58 \mathrm{a}$ \\
\hline \multirow{4}{*}{250} & CK3 & $4.25 \pm 0.49 b$ & $38.70 \pm 0.53 c$ & $28.68 \pm 0.57 c$ & $12.26 \pm 0.87 b$ \\
\hline & B1 & $6.06 \pm 0.65 a$ & $41.14 \pm 0.16 b$ & $21.56 \pm 0.10 \mathrm{~d}$ & $13.47 \pm 0.37 b$ \\
\hline & B2 & $5.86 \pm 0.72 \mathrm{a}$ & $46.35 \pm 1.79 a$ & $51.92 \pm 1.25 a$ & $20.73 \pm 1.26 a$ \\
\hline & B3 & $3.76 \pm 0.08 \mathrm{~b}$ & $42.39 \pm 0.35 b$ & $32.04 \pm 0.07 b$ & $13.68 \pm 0.38 b$ \\
\hline \multirow{4}{*}{500} & CK4 & $3.62 \pm 0.95 c$ & $29.46 \pm 0.89 b$ & $18.80 \pm 0.47 b$ & $9.47 \pm 0.20 \mathrm{~b}$ \\
\hline & B1 & $4.58 \pm 0.10 \mathrm{bab}$ & $23.73 \pm 0.81 c$ & $13.07 \pm 0.08 c$ & $5.81 \pm 0.02 \mathrm{~d}$ \\
\hline & B2 & $5.19 \pm 0.14 a$ & $32.81 \pm 1.60 \mathrm{a}$ & $28.24 \pm 0.39 a$ & $22.43 \pm 0.61 \mathrm{a}$ \\
\hline & B3 & $4.08 \pm 0.09 b c$ & $23.06 \pm 0.07 c$ & $8.36 \pm 0.24 d$ & $8.08 \pm 0.84 c$ \\
\hline \multirow{4}{*}{1000} & CK5 & $3.33 \pm 0.01 \mathrm{c}$ & $27.45 \pm 0.41 \mathrm{a}$ & $7.56 \pm 0.50 \mathrm{a}$ & $8.76 \pm 0.21 \mathrm{a}$ \\
\hline & B1 & $3.99 \pm 0.46 b$ & $18.25 \pm 0.02 b$ & $7.18 \pm 0.05 a$ & $7.41 \pm 0.01 b$ \\
\hline & B2 & $4.93 \pm 0.03 a$ & $16.47 \pm 0.49 \mathrm{c}$ & $4.20 \pm 0.07 b$ & $5.17 \pm 0.03 d$ \\
\hline & B3 & $3.29 \pm 0.01 c$ & $18.87 \pm 1.03 b$ & $7.36 \pm 0.12 a$ & $6.08 \pm 0.22 c$ \\
\hline \multirow{4}{*}{2000} & CK6 & $1.86 \pm 0.048 c$ & $6.41 \pm 0.31 d$ & $1.62 \pm 0.08 \mathrm{~d}$ & $1.99 \pm 0.03 c$ \\
\hline & B1 & $3.26 \pm 0.01 \mathrm{a}$ & $8.91 \pm 0.03 b$ & $3.56 \pm 0.19 b$ & $2.82 \pm 0.02 b$ \\
\hline & B2 & $2.40 \pm 0.07 b$ & $11.16 \pm 0.05 a$ & $4.04 \pm 0.20 \mathrm{a}$ & $3.57 \pm 0.03 a$ \\
\hline & B3 & $1.85 \pm 0.04 c$ & $7.53 \pm 0.47 c$ & $2.42 \pm 0.01 \mathrm{c}$ & $2.81 \pm 0.02 b$ \\
\hline
\end{tabular}

CK, B1, B2 and B3 respectively represent the control group (treated with sterile water), $10^{8} \mathrm{CFU} / \mathrm{ml}$ B. subtilis QM3 (B1), $10^{7} \mathrm{CFU} / \mathrm{ml} \mathrm{B.} \mathrm{subtilis}$ QM3 (B2) and $10^{6} \mathrm{CFU} / \mathrm{ml}$ B. subtilis QM3 (B3). Len, SA, Vol and PA in the table respectively represent the root length, the root surface area, the root volume and the root projection area. Values in the table are given as mean \pm SD for 3 replicates. Different letters in the same column mean significant difference among treatments at $0.05(\mathrm{p}<0.05)$. 
$\mathrm{Pb}$ stress, B. subtilis QM3 had an obvious promotion effect on root growth, root length (Len), compared with CK1, B1, B2 and B3 respectively increased by $76.82 \%, 91.78 \%$ and $77.76 \%$; surface area (SA) compared with CK1, B1, B2 and B3 respectively increased by $56.58 \%, 261.30 \%$ and $103.33 \%$; volume (Vol) compared with CK1, B1, B2 and B3 respectively increased by $193.11 \%, 634.55 \%$ and $196.92 \%$; projection area (PA) compared with CK1, B1, B2 and B3 respectively increased by 58.22\%, 277.30\% and 104.93\%. Without B. subtilis QM3 treatment, even a low $\mathrm{Pb}^{2+}$ concentration did have effect on root growth, under $50 \mathrm{mg} / \mathrm{L} \mathrm{Pb}^{2+}$ concentration, root morphology index reached the maximum, Len was obviously higher than those without $\mathrm{Pb}$ concentration, increased by $131.96 \%$, under $250,500,1000,2000 \mathrm{mg} / \mathrm{L} \mathrm{Pb}^{2+}$ concentration, Len was significantly inhibited; under 50, 250 and $500 \mathrm{mg} / \mathrm{L} \mathrm{Pb}^{2+}$ concentration, SA was obviously higher than those without $\mathrm{Pb}$ concentration, under 50 and $250 \mathrm{mg} / \mathrm{L} \mathrm{Pb}^{2+}$ concentration, Vol and PA were obviously higher than those without $\mathrm{Pb}$ concentration, this result indicated that the root length was the most affected by lead stress, but under 1000 and 2000 $\mathrm{mg} / \mathrm{L} \mathrm{Pb}^{2+}$ concentration, Len, SA, Vol and PA were all inhibited. Appearing above phenomenon may due to the dual role of $\mathrm{Pb}$ in plant, low $\mathrm{Pb}^{2+}$ concentration can promote the growth of plants. When $\mathrm{Pb}^{2+}$ was $500 \mathrm{mg} / \mathrm{L}$, Len compared with CK1, CK4, B1, B2 and B3 respectively reduced by 32.34\%, 14.39\%, 2.99\% and 27.74\%, B1, B2 and $\mathrm{B} 3$ all had alleviation effect on root under lead stress; When $\mathrm{Pb}^{2+}$ was $1000 \mathrm{mg} / \mathrm{L}$, Len compared with CK1, CK5, B1, B2 and B3 respectively reduced by 37.76\%, 25.42\%, 7.85\% and 38.50\%, B1 and B2 had a mitigation effect, B3 is the opposite. When $\mathrm{Pb}^{2+}$ concentration were 50, 250, 500, 1000, $2000 \mathrm{mg} / \mathrm{L}$, not all concentrations of the B. subtilis QM3 bacteria liquid have a role in remission, and between different $\mathrm{Pb}^{2+}$ concentration stress, the effect of the same concentration of $B$. subtilis QM3 is different. There is no fixed promotion relationship between different concentration of $B$. subtilis QM3 bacteria liquid and root morphology under lead stress, but in a certain degree, $B$. subtilis QM3 had an alleviation effect on the growth of the wheat root under lead stress.

\subsection{Mitigative Effect of $B$, subtilis QM3 on SOD Activity}

$\mathrm{Pb}\left(\mathrm{NO}_{3}\right)_{2}$ treatment caused an induction in the activity of SOD (Figure 1). With the increase of lead concentration, SOD activity of B1, B2 and B3 treatments for wheat root and the CK showed a tendency that SOD activity were increased and then decreased. Basically under the $\mathrm{Pb}$ concentration of $50 \mathrm{mg} / \mathrm{L}$ SOD activity reached the maximum, compared with CK, B1, B2 and B3 respectively increased by $8.05 \%, 27.41 \%$ and $9.79 \%$. Under lead concentrations were $0 \mathrm{mg} / \mathrm{L}, 50 \mathrm{mg} / \mathrm{L}, 250 \mathrm{mg} / \mathrm{L}, 500 \mathrm{mg} / \mathrm{L}$, SOD activity of wheat root under the treatment of B1, B2 and B3 were higher than that of CK, while under the lead concentrations were $1000 \mathrm{mg} / \mathrm{L}$ and 2000 $\mathrm{mg} / \mathrm{L}$, SOD activity had no regular variation. When $\mathrm{Pb}$ concentration was $1000 \mathrm{mg} / \mathrm{L}$, there's no difference between CK, B1 and B3, while the activity of B2 treatment was the lowest. When Pb concentration was 2000

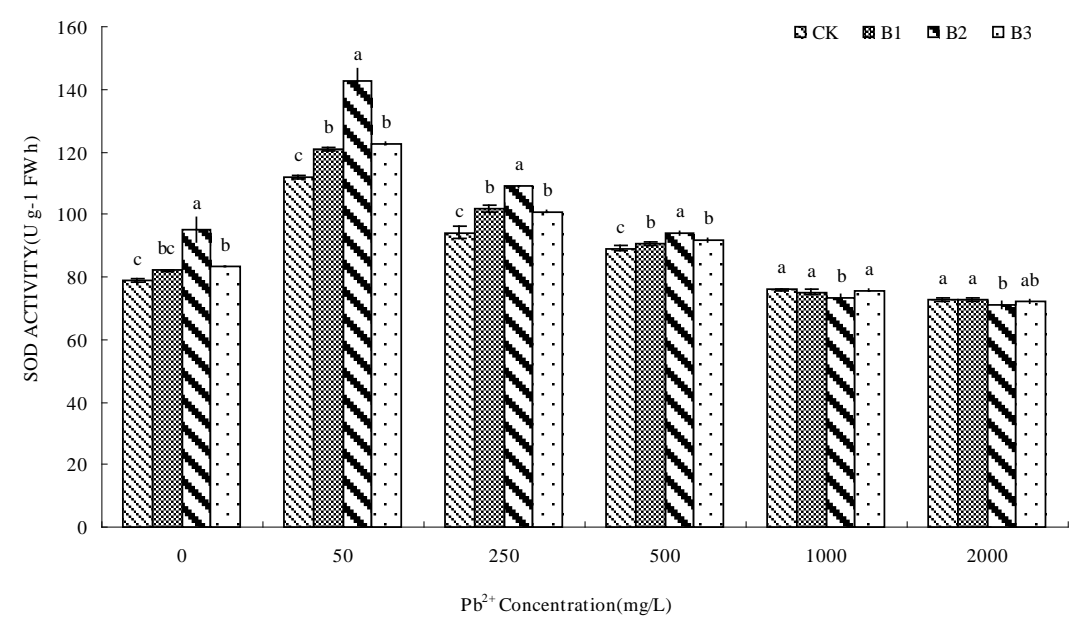

Figure 1. Effects of $B$. subtilis QM3 on SOD activity of wheat root under different lead stress. CK, B1, B2 and B3 respectively represent the control group (treated with sterile water), $10^{8} \mathrm{CFU} / \mathrm{ml}$ B. subtilis QM3 (B1), $10^{7} \mathrm{CFU} / \mathrm{ml}$ B. subtilis QM3 (B2) and $10^{6} \mathrm{CFU} / \mathrm{ml} \mathrm{B}$. subtilis QM3 (B3). Values in the chart are given as mean \pm SD for 3 replicates. Different letters in the same $\mathrm{Pb}^{2+}$ concentration column mean significant difference among treatments $(\mathrm{p}<0.05)$. 
$\mathrm{mg} / \mathrm{L}, \mathrm{CK}$ and B1 treatment had a slightly higher activity than B2 and B3. In the Pb solution concentrations were $0 \mathrm{mg} / \mathrm{L}, 50 \mathrm{mg} / \mathrm{L}, 250 \mathrm{mg} / \mathrm{L}, 500 \mathrm{mg} / \mathrm{L}$, SOD activity of $B$. subtilis QM3 treatment was enhanced obviously than CK. While the lead concentration were $1000 \mathrm{mg} / \mathrm{L}$ and $2000 \mathrm{mg} / \mathrm{L}$, among different treatments there's a little change in the activity of SOD.

\subsection{Mitigative Effect of $B$. subtilis QM3 on CAT Activity}

With the increasing of lead concentration, the result showed a tendency that CAT activity were increased and then decreased (Figure 2). Under the $\mathrm{Pb}$ concentration of $500 \mathrm{mg} / \mathrm{L}$ CAT activity reached the maximum, compared with CK, B1, B2 and B3 respectively increased by 59.93\%, 83.46\% and 70.59\%. On the whole, CAT activity of wheat root under the treatment of B1, B2 and B3 were higher than that of CK, and B2 treatment was enhanced obviously than any other treatments. When the $\mathrm{Pb}^{2+}$ concentration were $2000 \mathrm{mg} / \mathrm{L}$, there 's no change between CK and B3, B1 treatment had the highest activity, however, B2 treatment had the lowest activity. Under the lead stress $(0,50,250,500,1000 \mathrm{mg} / \mathrm{L})$, B. Subtilis QM3 could improve CAT activity.

\subsection{Mitigative Effect of $B$. subtilis QM3 on APX Activity}

$\mathrm{Pb}\left(\mathrm{NO}_{3}\right)_{2}$ treatment caused APX activity of B1, B2 and B3 treatments for wheat root and the CK showed a tendency that APX activity were concomitant increased in roots at the range of low $\mathrm{Pb}$ treatment levels and then decreased under high levels of Pb treatment (Figure 3). Similar to CAT activity, APX activity of wheat root under the treatment of B1, B2 and B3 were higher than those in CK. Under the Pb concentration of $50 \mathrm{mg} / \mathrm{L}$ APX activity reached the maximum, compared with CK, B1, B2 and B3 respectively increased by $52.70 \%$, $111.15 \%$ and $96.28 \%$, B2 treatment was enhanced obviously than any other treatments.

\subsection{Mitigative Effect of $B$, subtilis QM3 on POD Activity}

With the increasing of lead concentration, POD activity of B1, B2 and B3 treatments for wheat root and CK showed a tendency that POD activity were increased in low $\mathrm{Pb}$ treatment levels and then decreased in high $\mathrm{Pb}$ treatment levels (Figure 4). At the Pb concentration was $500 \mathrm{mg} / \mathrm{L}$, POD activity reached the maximum, compared with CK, B1, B2 and B3 respectively increased by 2.88\%, 10.11\% and 7.67\%. Overall, under the high level lead stress (1000 mg/L), POD activity had no significantly difference between CK, B1 and B3, B2 had a slightly higher POD activity. Under the lead concentrations were $0 \mathrm{mg} / \mathrm{L}, 50 \mathrm{mg} / \mathrm{L}, 250 \mathrm{mg} / \mathrm{L}, 500 \mathrm{mg} / \mathrm{L}$ and $2000 \mathrm{mg} / \mathrm{L}$, POD activity of B1, B2 and B3 treatments for wheat root were higher than that of the CK.

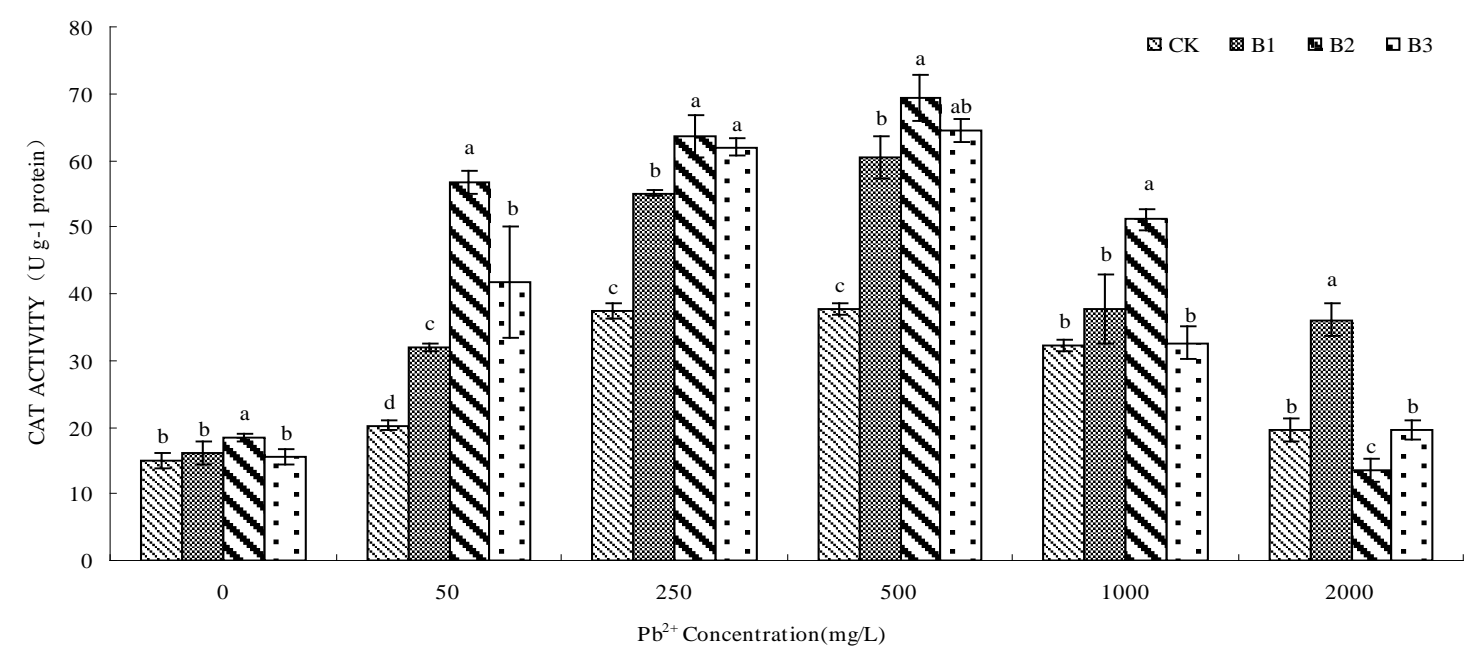

Figure 2. Effects of B. Subtilis QM3 on CAT activity of wheat root under different lead stress. CK, B1, B2 and B3 respectively represent the control group (treated with sterile water), $10^{8} \mathrm{CFU} / \mathrm{ml} B$. subtilis QM3 (B1), $10^{7} \mathrm{CFU} / \mathrm{ml}$ B. subtilis QM3 (B2) and $10^{6} \mathrm{CFU} / \mathrm{ml}$ B. subtilis QM3 (B3). Values in the chart are given as mean \pm SD for 3 replicates. Different letters in the same $\mathrm{Pb}^{2+}$ concentration column mean significant difference among treatments $(\mathrm{p}<$ 0.05 ). 


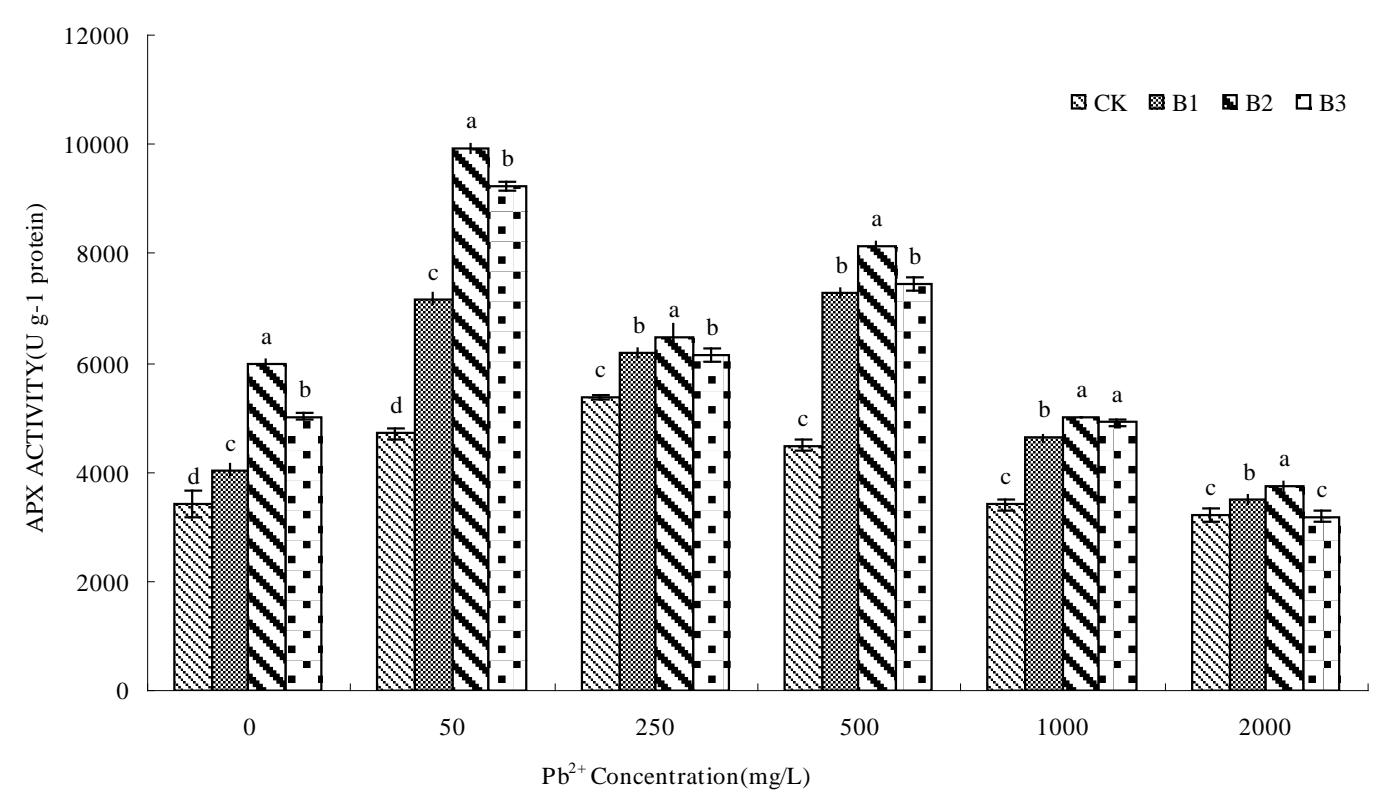

Figure 3. Effects of B. subtilis QM3 on APX activity of wheat root under different lead stress. CK, B1, B2 and $\mathrm{B} 3$ respectively represent the control group (treated with sterile water), $10^{8} \mathrm{CFU} / \mathrm{ml} \mathrm{B}$. subtilis QM3 (B1), $10^{7}$ $\mathrm{CFU} / \mathrm{ml}$ B. subtilis QM3 (B2) and $10^{6} \mathrm{CFU} / \mathrm{ml}$ B. subtilis QM3 (B3). Values in the chart are given as mean \pm $\mathrm{SD}$ for 3 replicates. Different letters in the same $\mathrm{Pb}^{2+}$ concentration column mean significant difference among treatments $(\mathrm{p}<0.05)$.

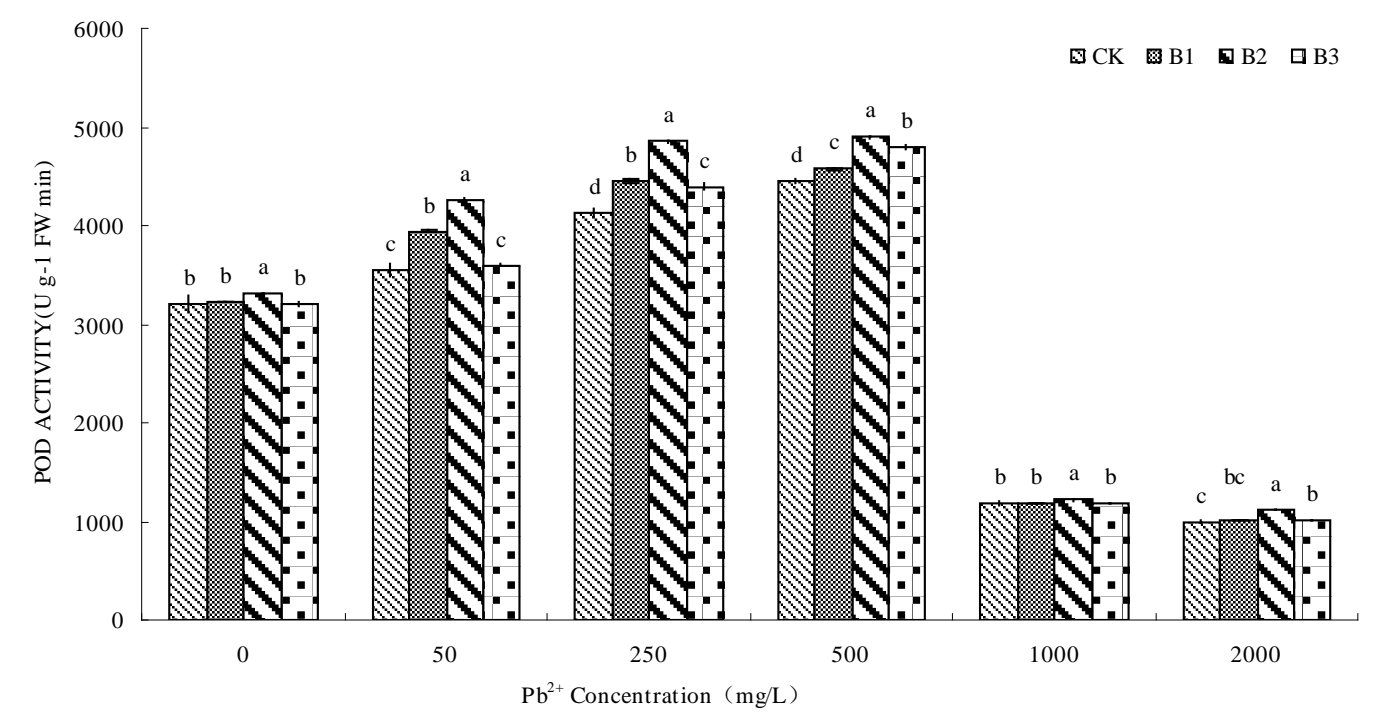

Figure 4. Effects of Bacillus subtilis QM3 on POD activity of wheat root under different lead stress. Values in the chart are given as mean $\pm S D$ for 3 replicates. CK, B1, B2 and B3 respectively represent the control group (treated with sterile water), $10^{8} \mathrm{CFU} / \mathrm{ml} \mathrm{B}$. subtilis QM3 (B1), $10^{7} \mathrm{CFU} / \mathrm{ml}$ B. subtilis QM3 (B2) and $10^{6} \mathrm{CFU} / \mathrm{ml}$ B. subtilis QM3 (B3). Different letters in the same $\mathrm{Pb}^{2+}$ concentration column mean significant difference among treatments $(\mathrm{p}<0.05)$.

\section{Discussion}

Lead is one of the most abundant heavy metals polluting the soil environment [17]-[20]. It is readily absorbed by plants mainly through the root system and thereafter exerts its toxicity symptoms. The effects of Pb phytotoxicity include stunted growth, chlorosis, blackening of the root systems [18], alteration in water and nutritional status of plants [15] as well as various plant processes [18] [20]. 
A number of reports have showed the inhibitory and toxic effect of different heavy metal on the germination of seeds and the growth of plant seedling [21] [22]. It is well known that root growth is more sensitive than seed germination to metal toxicity [23] [24]. In addition, because plant roots are the first point of contact for heavy metal toxic factors, the reduction in root length was more prominent in plants when exposed to different of $\mathrm{Pb}$ and Cd treatments in comparison with the growth of shoots [25] [26]. Some researches [27]-[29] found that low concentrations of $\mathrm{Pb}$ in the nutrient solution stimulated seed germination, while high concentrations resulted in the inhibitory effect, suggesting the dual role of $\mathrm{Pb}$ in plant. Our result showed that lead stress caused a significant inhibition on wheat root growth, including the root length, root surface area, root volume and root projection area. However, under $50 \mathrm{mg} / \mathrm{L} \mathrm{Pb}^{2+}$ concentration, the wheat root growth was promoted, it may due to the dual role of $\mathrm{Pb}$ in plant. From other $\mathrm{Pb}^{2+}$ concentrations stress, in a certain degree, B. subtilis QM3 had an alleviation effect on the growth of the wheat root under lead stress.

In many plant species heavy metals have been reported to cause oxidative damage due to production of ROS [4] [7] [30]-[32]. To resist oxidative damage, the antioxidant enzymes and certain metabolites present in plants play an important role leading to adaptation and ultimate survival of plants during periods of stress [16] [32]. Induction in the activities of antioxidative enzymes is a general strategy adopted by plants to overcome oxidative stress due to the imposition of environmental stresses [7] [33].

The current results show an increase of SOD activity in wheat seedlings growing in the presence of lead. SOD considered as a first defense against ROS as it acts on superoxide radicals, which are produced in different compartments of the cell and are precursors of the other ROS [34]. Increase in SOD activity is attributed to the increase in superoxide radical concentrations.

CAT activity increases under lead phytotoxicity, and this increase can be also explained by a substrate induction, in order to maintain low levels of $\mathrm{H}_{2} \mathrm{O}_{2}$ as an adaptive mechanism [35].

POD is located in cytosol, cell walls, vacuoles and extracellular spaces. It is considered as stress marker enzyme having a broad specificity for phenolic substrates and a higher affinity for $\mathrm{H}_{2} \mathrm{O}_{2}$ than CAT. POD consumes $\mathrm{H}_{2} \mathrm{O}_{2}$ to generate phenoxy compounds that are polymerized to produce cell wall components such as lignans [35]. Increase in POD is correlated with lead stress suggesting it to be an intrinsic defense tool [10].

Our results show that resistance enzyme activity increased in low $\mathrm{Pb}^{2+}$ concentration level, the results of our experiments are same as the results of the previous studies, plants can resist the heavy metal stress by improving the activity of the resistance enzymes. Whereas resistance enzyme activity decreased in high $\mathrm{Pb}^{2+}$ concentration level $(1000,2000 \mathrm{mg} / \mathrm{L})$. In the same $\mathrm{Pb}^{2+}$ concentration treatment, enzyme activity of wheat root under the treatment of B1, B2 and B3 were higher than that of CK, and B2 treatment was enhanced obviously than any other treatments. While under high concentration of $\mathrm{Pb}^{2+}(1000,2000 \mathrm{mg} / \mathrm{L})$, each index had little change.

The results suggest that under low $\mathrm{Pb}^{2+}$ concentration, wheat roots can show a strong ability of antioxidant by improving the resistant enzyme activities; In the low $\mathrm{Pb}^{2+}$ concentration, compared with the control group, the treatment of $B$. subtilis QM3 contributed to enzymes activity of the wheat root improved to a certain degree, so as to restrain the excessive accumulation of reactive oxygen caused by lead stress, reduce lipid peroxidation of cell membrane and maintain the relative integrity and orderliness, at last, relieved the inhibition to the root system growth. By comparison, $10^{7} \mathrm{CFU} / \mathrm{ml}$ B. subtilis QM3 bacteria liquid treatment was enhanced obviously than any other treatments. $10^{8} \mathrm{CFU} / \mathrm{ml}$ B. subtilis QM3 has a higher concentration, and $10^{6} \mathrm{CFU} / \mathrm{ml}$ B. subtilis QM3 has a lower concentration, these two reasons may lead to their alleviate effect are not as good as $10^{7} \mathrm{CFU} / \mathrm{ml} B$. subtilis QM3 solution. However, plant self-protection ability is limited, When the $\mathrm{Pb}^{2+}$ concentration over 1000 $\mathrm{mg} / \mathrm{L}$, membrane lipid system of wheat roots would be thoroughly damaged by active oxygen, the activities of the resistant enzyme are reduced, at the same time the treatment of $B$. subtilis QM3 solution to wheat root that under high level of $\mathrm{Pb}^{2+}(>1000 \mathrm{mg} / \mathrm{L})$ had no obvious relieve effect on SOD and POD activity. Lead concentration was too high to cause plant excessive injury, lead to alleviate effect not obvious.

\section{Conclusion}

Plant-associated bacteria can have beneficial effects on the growth of their host. Nevertheless, the role of plant growth promoting bacteria, in terms of plant metal stress tolerance, has not been investigated in depth. When the plants exposed to $\mathrm{Pb}$, the bacterium depressed $\mathrm{Pb}$ induced oxidative stress by improving antioxidant enzymes (SOD, CAT, APX, POD), promoted relative plant growth, resulting in increased plant tolerance to $\mathrm{Pb}$. The result indicated that $B$. subtilis QM3 promoted better growth in plants cultivated in the presence of $\mathrm{Pb}$. This phenome- 
non appears to be attributed to a mechanism that decreases $\mathrm{Pb}$ concentrations in the root via a beneficial interaction between the bacteria and the plant roots.

\section{Acknowledgements}

This work was supported by program for the Top Young Academic Leaders of Higher Learning Institutions of Shanxi. We are grateful to the anonymous reviewers for critical comments which have helped in improving the manuscript.

\section{References}

[1] Hernberg, S. (2000) Lead Poisoning in A Historical Perspective. American Journal of Industrial Medicine, 38, 244254. http://dx.doi.org/10.1002/1097-0274(200009)38:3<244::AID-AJIM3>3.0.CO;2-F

[2] Comba, M.E., Benavides, M.P. and Tomaro, M.L. (1998) Effect of Salt Stress on Antioxidant Defence System in Soybean Root Nodules. Australian Journal of Plant Physiology, 25, 665-671. http://dx.doi.org/10.1071/PP97156

[3] Baisak, R., Rana, D.A., Acharya, P.B.B. and Kar, M. (1994) Alterations the Activities of Active Oxygen Scavenging Enzymes of Wheat Leaves Subjected to Water Stress. Plant and Cell Physiology, 35, 489-495.

[4] Shah, K., Kumar, R.G., Verma, S. and Dubey, R.S. (2001) Effect of Cadmium on Lipid Peroxidation, Superoxide Anion Generation and Activities of Antioxidant Enzymes in Growing Rice Seedlings. Plant Science, 161, 1135-1144. http://dx.doi.org/10.1016/S0168-9452(01)00517-9

[5] Mishra, R.K. and Singhal, G.S. (1992) Function of Photosynthetic Apparatus of Intact Wheat Leaves under High Light and Heat Stress and Its Relationship with Peroxidation of Thylakoid Lipids. Plant Physiology, 98, 1-6.

http://dx.doi.org/10.1104/pp.98.1.1

[6] Becana, M., Dalton, D.A., Moran, J.F., Iturbe-Ormaetxe, I., Matamoros, M.A. and Rubio, M.C. (2000) Reactive Oxygen Species and Antioxidants in Legume Nodules. Plant Physiology, 109, 372-381. http://dx.doi.org/10.1034/j.1399-3054.2000.100402.x

[7] Malecka, A., Jarmuszkiewicz, W. and Tomaszewska, B. (2001) Antioxidative Defense to Lead Stress in Subcellular Compartments of Pea Root Cells. Acta Biochimica Polonica, 48, 687-698.

[8] Posmyk, M.M., Kontek, R. and Janas, K.M. (2009) Antioxidant Enzymes Activity and Phenolic Compounds Content in Red Cabbage Seedlings Exposed to Copper Stress. Ecotoxicology and Environmental Safety, 72, 596-602. http://dx.doi.org/10.1016/j.ecoenv.2008.04.024

[9] Mishra, A. and Choudhair, M.A. (1998) Amelioration of Lead and Mercury Effects on Germination and Rice Seedling Growth by Antioxydants. Plant Biology, 41, 469-473. http://dx.doi.org/10.1023/A:1001871015773

[10] Verma, S. and Dubey, R.S. (2003) Lead Toxicity Induces Lipid Peroxidation and Alters the Activities of Antioxidant Enzymes in Growing Rice Plants. Plant Science, 164, 645-655. http://dx.doi.org/10.1016/S0168-9452(03)00022-0

[11] Ewa, G. and Maria, S. (2010) Differential Effect of Equal Copper, Cadmium and Nickel Concentration on Biochemical Reactions in Wheat Seedlings. Ecotoxicology and Environment Safety, 73, 996-1003. http://dx.doi.org/10.1016/j.ecoenv.2010.02.013

[12] Dhindsa, S.R. and Matowe, W. (1981) Drought Tolerance in Two Mosses: Correlated with Enzymatic Defence against Lipid Peroxidation. Journal of Experimental Botany, 32, 79-91. http://dx.doi.org/10.1093/jxb/32.1.79

[13] Beers, R.F. and Sizer, I.W. (1952) Colorimetric Method for Estimation of Catalase. The Journal of Biological Chemistry, 195, 133-139.

[14] Moran, J.F., Becana, M.I., Frechilla, I.S., Klucas, R.V. and Aparicio-Tejo, P. (1994) Drought Induced Oxidative Stress in Pea Plants. Planta, 194, 346-352. http://dx.doi.org/10.1007/BF00197534

[15] Nakano, Y. and Asada, K. (1981) Hydrogen Peroxide is Scavenged by Ascorbate-Specific Peroxidase in Spinach Chloroplasts. Plant and Cell Physiology, 22, 867-880.

[16] Bradford, M.M. (1976) A Rapid and Sensitive Method for Quantification of Microgram Quantities of Protein Utilizing the Principle of Protein-Dye Binding. Analytical Biochemistry, 72, 248-254. http://dx.doi.org/10.1016/0003-2697(76)90527-3

[17] Eick, M.J., Peak, J.D., Brady, P.V. and Pesek, J.D. (1999) Kinetics of Lead Absorption/Desorption on Goethite: Residence Time Effect. Soil Science, 164, 28-39. http://dx.doi.org/10.1097/00010694-199901000-00005

[18] Godbold, D.L. and Kettner, C. (1991) Lead Influences Root Growth and Mineral Nutrition of Picea abies Seedlings. Journal of Plant Physiology, 139, 95-99. http://dx.doi.org/10.1016/S0176-1617(11)80172-0

[19] Moustakas, M., Lanaras, T., Symeonidis, L. and Karataglis, S. (1994) Growth and Some Photosynthetic Characteristics of Field Grown Avena sativa under Copper and Lead Stress. Photosynthetica, 30, 389-396. 
[20] Kastori, R., Petrovic, M. and Petrovic, N. (1992) Effect of Excess Lead, Cadmium, Copper and Zinc on Water Relations in Sunflower. Journal of Plant Nutrition, 15, 2427-2439. http://dx.doi.org/10.1080/01904169209364485

[21] Kopyra, M. and Gwozdz, E.A. (2003) Nitric Oxide Stimulates Seeds Germination and Counteracts the Inhibitory Effect of Heavy Metals and Salinity on Root Growth of Lupinus luteus. Plant Physiology and Biochemistry, 41, 10111017. http://dx.doi.org/10.1016/j.plaphy.2003.09.003

[22] Atici, O., Agar, G. and Battal, P. (2005) Changes in Phytohormone Contents in Chickpea Seeds Germinating under Lead or Zinc Stress. Biologia Plantarum, 49, 215-222. http://dx.doi.org/10.1007/s10535-005-5222-9

[23] Araujo, A.S.R. and Monteiro, R.T.R. (2005) Plant Bioassays to Assess Toxicity of Textile Sludge Compost. Scientia Agricola (Piracicaba Brazil), 62, 286-290. http://dx.doi.org/10.1590/s0103-90162005000300013

[24] Iqbal, M.Z. and Rehman, S.A. (2002) Effects of Cd, Zn, Cr and Pb on Seed Germination and Seedling Growth of Plants. Pakistan Journal of Environmental Science, 1, 47-53.

[25] Faheed, F.A. (2005) Effect of Lead Stress on Growth and Metabolism of Eruca sativa M. Seedlings. Acta Agronomica Hungarica, 53, 319-327. http://dx.doi.org/10.1556/AAgr.53.2005.3.9

[26] Kabir, M., Zafar Iqbal, M., Shafiq, M. and Farooqi, Z.R. (2008) Reduction in Germination and Seedling Growth of Thespesia populnea L., Caused by Lead and Cadmium Treatments. Pakistan Journal of Botany, 40, 2419-2426.

[27] Leyval, C., Turnau, K. and Haselwandter, K. (1997) Effect of Heavy Metal Pollution on Mycorrhizal Colonization and Function: Physiological, Ecological and Applied Aspects. Mycorrhiza, 7, 139-153. http://dx.doi.org/10.1007/s005720050174

[28] Somova, L.A. and Pechurkin, N.S. (2009) The Influence of Microbial Associations on Germination of Wheat Seeds and Growth of Seedlings under Impact of Zinc Salts. Advances in Space Research, 43, 1224-1228. http://dx.doi.org/10.1016/j.asr.2008.12.008

[29] Li, C.X., Feng, S.L., Shao, Y., Jiang, L.N., Lu, X.Y. and Hou, X.L. (2007) Effect of Arsenic on Seed Germination and Physiological Activities of Wheat Seedlings. Journal of Environment Sciences, 19, 725-732. http://dx.doi.org/10.1016/S1001-0742(07)60121-1

[30] Cakmak, I. and Horst, W.J. (1991) Effect of Aluminium on Lipid Peroxidation, Superoxide Dismutase, Catalase and Peroxidase Activities in Root Tips of Soybean (Glycine max). Physiologia Plantarum, 83, 463-468. http://dx.doi.org/10.1111/j.1399-3054.1991.tb00121.x

[31] Chaoui, A., Mazhoudi, S., Ghorbal, M.H. and El-Ferjani, E. (1997) Cadmium and Zinc Induction of Lipid Peroxidation and Effects on Antioxidant Enzyme Activities in Bean (Phaseolus vulgaris L.). Plant Science, 127, 139-147. http://dx.doi.org/10.1016/S0168-9452(97)00115-5

[32] Prasad, K.V.S.K., Saradhi, P.P. and Sharmila, P. (1999) Concerted Action of Antioxidant Enzymes and Curtailed Growth under Zinc Toxicity in Brassica juncea. Environmental and Experimental Botany, 42, 1-10. http://dx.doi.org/10.1016/S0098-8472(99)00013-1

[33] Foyer, C.H., Descourviers, P. and Kunert, K.J. (1994) Protection Oxygen Radicals: An Important Defense Mechanism Studied in Transgenic Plant. Plant, Cell \& Environment, 17, 507-523. http://dx.doi.org/10.1111/j.1365-3040.1994.tb00146.x

[34] Alscher, R.G., Erturk, N. and Heath, L.S. (2002) Role of Superoxide Dismutases (SODs) in Controlling Oxidative Stress in Plant. Journal of Experimental Botany, 53, 1331-1341. http://dx.doi.org/10.1093/jexbot/53.372.1331

[35] Reddy, A.M., Kumar, S.G., Jyonthsnakumari, G., Thimmanaik, S. and Sudhakar, C. (2005) Lead Induced Changes in Antioxidant Metabolism of Horsegram (Macrotyloma uniflorum [Lam.] Verdc.) and Bengalgram (Cicer arietinum L.). Chemosphere, 60, 97-104. http://dx.doi.org/10.1016/j.chemosphere.2004.11.092 